\title{
Artan Çocukluk Çağı Obezitesi ve Fokal Segmental Glomeruloskleroz (FSGS): İki Olgu Sunumu
}

Increased Childhood Obesity and Focal Segmental Glomerulosclerosis (FSGS): Two Case Reports

\author{
Nevra Koç ${ }^{1}$, Umut Selda Bayrakc1 ${ }^{2}$
}

Geliş tarihi/Received: 14.03 .2018 • Kabul tarihi/Accepted: 16.11.2018

\section{ÖZET}

Çocuklarda nefrotik sendrom nedeni olarak en sık minimal değişiklik hastalığı olarak gözlemlenirken, ikinci sırayı fokal segmental glomerüloskleroz (FSGS) almaktadır. FSGS primer veya sekonder nedenlere bağlı oluşabilmektedir. Sekonder nedenler arasında morbid obezite sıklığının gittikçe arttığı dikkati çekmektedir. Yapılan çalışmalarda vücut ağırlığındaki düşüşün proteinüride azalma ile ilişkilendirildiği gösterilmiştir. Bu amaçla obezite ile ilişkili FSGS olan adölesan iki olgunun tıbbi tedavisi ve diyet yönetimi makalede tartışılacaktır.

Anahtar kelimeler: Çocuklarda nefrotik sendrom, diyet yönetimi, fokal segmental glomerüloskleroz

\begin{abstract}
The most common cause of nephrotic syndrome in children is the minimal change disease, followed by focal segmental glomerulosclerosis (FSGS). FSGS may be caused by primary or secondary causes. Among the secondary causes, the incidence of increased morbid obesity is noteworthy. The studies have shown that body weight loss is associated with a significant reduction in proteinuria. For this purpose, dietary management and medical treatment of two adolescents with obesityrelated FSGS will be discussed in our article.
\end{abstract}

Keywords: Nephrotic syndrome in children, dietary management, focal segmental glomerulosclerosis, obesity surgery

\section{GíRiş}

Nefrotik sendrom, proteinüri, hipoalbüminemi, hiperkolesterolemi ve ödem ile karakterizedir. Nefrotik sendromdaki primer renal anormallik, artmış glomeruler permeabiliteye bağlı proteinüri iken hipoalbüminemi, ödem ve hiperkolesterolemi sekonder olarak oluşan fizyopatolojik olaylardır. Çocuklarda nefrotik sendrom nedeni olarak en sık

1. İletişim/Correspondence: Sağlık Bilimleri Üniversitesi Ankara Çocuk Sağlığı ve Hastalıkları Hematoloji Onkoloji Eğitim ve Araştırma Hastanesi Beslenme ve Diyet Bölümü, Ankara, Türkiye

E-posta: nevrakoc@yahoo.com • i https://orcid.org/0000-0002-4358-4443 minimal değişiklik hastalığı karşımıza çıkarken, ikinci sırayı fokal segmental glomerüloskleroz (FSGS) almaktadır. Son yıllarda FSGS’nin görülme sıklığı, minimal değişiklik hastalığına göre artmıştır (1). FSGS histolojik bir tanımlama olup primer veya sekonder nedenlere bağlı oluşabilir. Primer FSGS'li olguların çoğu asemptomatik proteinüri veya nefrotik sendrom

2. Yıldırım Beyazit Üniversitesi Tıp Fakültesi Çocuk Sağlığı ve Hastalıkları Ana Bilim Dalı, Çocuk Nefroloji Bilim Dalı, Ankara, Türkiye (D) https://orcid.org/0000-0002-5301-2617 
şeklinde ortaya çıkmaktadır. Sekonder nedenler arasında morbid obezite sıklığının gittikçe arttığı dikkati çekmektedir (2).

Şişmanlık ve obezite dramatik olarak dünya genelinde çocuk ve adolesanlarda artmaktadır. Epidemiyolojik çalışmalar obezitenin böbrek hastalıkları için bir risk etmeni olduğunu göstermiştir. Obezitenin yanı sira diyabet ve arteriyel hipertansiyonun, diğer komorbiditeler gözlemlenmese de böbrek hastalığı ve son dönem böbrek yetmezliğine geçişi hızlandırdığı bildirilmiştir (3). Erişkinlerde kronik böbrek hastalıklarının \%14-30’unun şişmanlık/obezite ile ilişkili olduğu gösterilmiştir (4).

Obezite ile ilişkili FSGS ve primer FSGS'nin histolojik ve klinik farkları Tablo 1'de özetlenmiştir $(4,5)$.

Tablo 1. Obezite ile ilişkili FSGS ve primer FSGS'nin histolojik ve klinik farkları $(4,5)$

\begin{tabular}{ll}
\hline Obezite ile ilişkili FSGS & Primer FSGS \\
\hline Yavaş artan proteinüri & Aniden ortaya çıkan proteinüri \\
Hastaların çoğunda subnefrotik proteinüri görülür & Hastaların çoğunda nefrotik düzeyde proteinüri görülür. \\
$\begin{array}{l}\text { Hastada masif proteinüri olsa bile nefrotik sendrom (ödem, } \\
\text { hipoalbüminemi) gözlenmez }\end{array}$ & $\begin{array}{l}\text { Sılıkla nefrotiksendrom bulguları gözlemlenir } \\
\text { Glomerülomegali }\end{array}$ \\
$\begin{array}{l}\text { Elektron mikroskopik incelemede ayaksı çıkıntılarda } \\
\text { düzensiz silinmeler }\end{array}$ & $\begin{array}{l}\text { Elektron mikroskopik incelemede ayaksı çıkıntılarda diffüz } \\
\text { silinme }\end{array}$ \\
\hline
\end{tabular}

FSGS: Fokal segmental glomeruloskleroz

Yapılan randomize kontrollü çalışmalarla vücut ağırlığındaki düşüşün proteinüride önemli düzeyde azalma ile ilişkilendirildiği kanıtlanmıştır $(6,7)$. Vücut ağırlık kaybı ister diyet ister bariatrik cerrahi ile olsun beraberinde renin anjiotensinojen blokerleri ile birlikte tedavide kullanıldığında hastalığın ilerleyişini yavaşlatarak son dönem böbrek hastalığına gelinmesini önemli oranda azaltmaktadır.

$\mathrm{Bu}$ makalede obezite ile ilişkili olarak gelişen FSGS olan iki adolesan olgu ve uygulanan tıbbi ve tıbbi beslenme tedavisi tartışlacaktır.

\section{OLGU SUNUMU-1}

Morbido bezite ve genetik sendrom ile izlemli erkek olgu 14 yaşında olup, vücut ağırlığı $142.3 \mathrm{~kg}$ (+5 SD), boy uzunluğu $150.2 \mathrm{~cm}$ (-1.9 SD), boy uzunluğuna göre ideal ağırlığı 44.5 kg, beden kütle indeksi (BKİ) 58 kg/ $\mathrm{m}^{2}$ (+5 SD)'dır. Özel eğitim alan hasta, hastanemiz endokrinoloji polikliniğine başvurmuştur. Dört yaşından itibaren vücut ağırlığında hızlı bir artış öyküsü olan hastanın ailesinde akrabalık öyküsü, böbrekyetmezliğive diyalizöyküsübulunmamaktadır. Baba 41 yaşında kalp krizinden ex olmuştur.
Çocuk endokrinoloji polikliniği tarafından kan şekeri yüksekliği nedeniyle metformin HCL 2x100 mg/gün başlanan, 2000 kkal/gün 3 ana, 3 ara öğün diyabetik diyet alan hasta idrarda protein atımı nedeniyle Çocuk Nefroloji Polikliniği'ne yönlendirilmiştir. Fizik muayenede obezite dışında herhangi bir patolojik bulgusu olmayan hastanın tansiyonu 140/80 mmHg ölçülmüştür. Tam idrar tetkikinde $3+$ proteinürisi olan hastanın spot idrarda protein/kreatinin oranı 2.5 idi. Kan biyokimyasının değerlendirilmesinde serum albümin $2.5 \mathrm{mg} / \mathrm{dL}$, serum kreatinin $0.9 \mathrm{mg} / \mathrm{dL}$ bulunmuştur. Lipit profilinde total kolesterol düzeyi $310 \mathrm{mg} / \mathrm{dL}$, trigliserit $275 \mathrm{mg} / \mathrm{dL}$, HDL kolesterol $66 \mathrm{mg} / \mathrm{dL}$, LDL kolesterol 189 mg/dL'dir. Hastanın izleminde kan basıncının yüksek seyretmesi üzerine 24 saatlik ayaktan kan basıncı monitorizasyonu yapılmış ve genel değerlendirmede sistolik kan basıncı yükünün \%88, diyastolik kan basıncı yükünün \%75 olduğu saptanmıştır. Hipertansiyon tanısı alan olguya anjiyotensin dönüştürücü enzim inhibitörü ve anjiyotensin II antagonisti başlanmıştır. Çocuk Kardiyoloji Bölümü tarafından değerlendirilen hastanın yapılan ekokardiyografi incelemesi normal bulunmuştur. Göz muayenesinde hipertansif 
retinopati bulgusu yoktur. Nefrotik sendrom etiyolojisinin aydınlatılmasına yönelik yapılan renal biyopside hastanın morbid obezitesi nedeniyle yeterli doku elde edilememiş, sadece 2 glomerülün izlendiği ışık mikroskopik değerlendirmede bu glomerüllerin birinde global skleroz olduğu gözlenmiştir.

Ayrıca fiziksel olarak az aktif olan ve özel eğitime giden hasta $2100 \mathrm{kkal} 3$ ana, 3 ara diyabetik, kolesterolden kısitll ve $71 \mathrm{~g}$ proteinli tuzsuz diyet programına alınmıştır. Beraberinde klinik diyetisyeni tarafından tıbbi beslenme tedavisi eğitimi verilmiştir. Günlük vizitlerle besin tüketimi izlenmiştir. Ancak diyet uyumu yetersiz olan hastanın, fiziksel aktivitesinde de bir artış gözlenmemiştir. Yaklaşık 4 yıldır Çocuk Nefroloji ekibi tarafindan izlenen olguda nefrotik sendromun dönem dönem immünsupresif tedaviye kısmi yanıt vermesi nedeniyle immünolojik FSGS olabileceği düşünülmekle beraber hastanın tam remisyonda olduğu bir dönem olmamıştır. Tedavide steroid, siklosporin ve mikofenolatmofetil kullanılmış ancak hastanın tedaviye yanıtı sadece kısmi olmuştur.

Diyete uyumda oldukça zorlanan hastada aylık izlem ile vücut ağırlığındaki artış, tedavinin ilk iki yllı süresince yavaşlayarak devam etmiş ve vücut ağırlığı $160 \mathrm{~kg}$ düzeyine ulaşmış olup, son iki yılda vücut ağırlık kaybı sürecine girerek 155 kg’a kadar gerilemiştir. Boy uzunluğunda ise $5 \mathrm{~cm}$ 'lik bir artış olup, $155.2 \mathrm{~cm}$ düzeyine ulaşmıştır (Şekil 1). İzlem sürecinde kan albümin, üre, ürik asit ve kreatinin değerleri Şekil 2'de verilmiştir.

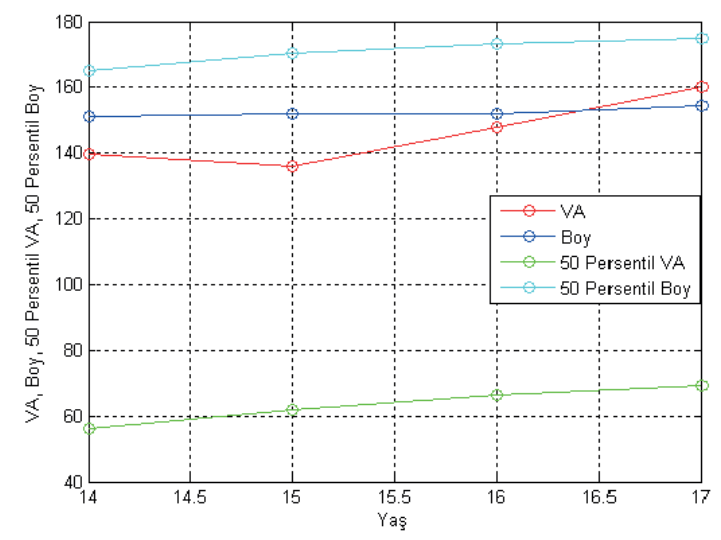

Şekil 1. Olgu 1'in izlem sürecinde vücut ağırlığı ve boy uzunluğu

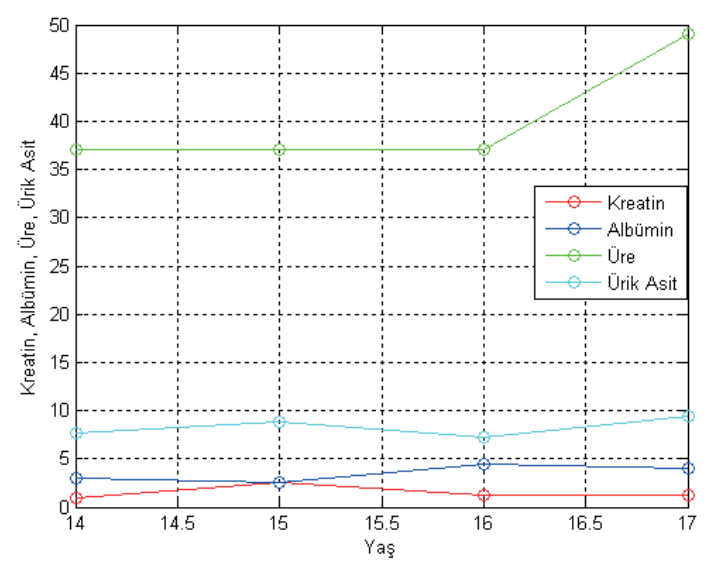

Şekil 2. Olgu 1'in izlem sürecinde bazı biyokimyasal bulguları

\section{OLGU SUNUMU- 2}

Tanı almadan iki ay önce ayaklarında şişlik olması nedeniyle doktora başvuran 15 yaşında kız olgunun, serum albümin düzeyi düşük (2.19 mg/dL), trigliserit (236 mg/dL) ve kolesterol (347mg/dL) düzeyleri yüksek olup, idrarda $3+$ proteinüri saptanması nedeniyle nefrotik hastalık tablosu ön tanısı ile hastanenin çocuk nefroloji polikliniğine yönlendirilmiştir.

Daha önce geçirilmiş bir hastalık öyküsü olmayan olgunun ailede, baba ve kuzenlerde yaygın nefrolitiazis öyküsü bulunmaktadır. Ayrıca ailede hipertansiyon, kalp damar hastalıkları, diyabet ve guatr olduğu da belirtilmiştir. Anne baba arasında uzak akrabalık söz konusudur.

Fizik muayenede belirgin bir ödemi olmayan hastanın kan basıncı 140/100 mmHg idi. Vücut ağırlığı 102.4 kg (+4.93 SD), boy uzunluğu $161.8 \mathrm{~cm}$ (+0.02 SD), boy uzunluğuna göre ideal ağırlığı $55.3 \mathrm{~kg}$, BKİ $39.1 \mathrm{~kg} / \mathrm{m}^{2}$ (+3.89 SD) olup, obezite saptanmıştır. Yatışı yapılan hastanın spot idrarda bakılan protein/kreatinin oranı 6.1 bulunmuştur (spot idrarda protein $741.0 \mathrm{mg} /$ dL, kreatinin $121 \mathrm{mg} / \mathrm{dL}$ ). Hastanın serum albümin düzeyi $2.3 \mathrm{mg} / \mathrm{dL}$, kreatinin düzeyi $0.85 \mathrm{mg} / \mathrm{dL}$ olarak saptanmıştır. Lipit profilinde total kolesterol düzeyi $350 \mathrm{mg} / \mathrm{dL}$, trigliserit düzeyi ise $150 \mathrm{mg} / \mathrm{dL}$ olarak bulunmuştur. Fiziksel olarak aktivitesi de oldukça az olan hastaya klinik diyetisyeni tarafindan 2100 kkal/ gün, tuzsuz, kolesterolden kısıtlı diyet başlanmıştır. 
Hastanın nefrotik sendrom etiyolojisinin aydınlatılması amacıyla yapılan böbrek biyopsisi "fokal segmental glomerüloskleroz" olarak raporlanmıştır. Hastaya oral steroid başlanmıştır. İzlemde tansiyon yüksekliği ve baş ağrıları devam eden hastada steroide bağlı yaygın kushingoid görünüm saptanması üzerine, tedaviye sadece kısmi yanit veren hastanın steroid tedavisi azaltılarak kesilmiş ve anjiyotensin II antagonisti başlanmıştır.

Tuzsuz diyete uyumu zayıf olan ve genel olarak porsiyonlarını da küçültemeyen hastanın vücut ağırlık artışı devam edip bir yılın sonunda 111 kg’a ulaşmıştır. Boy uzunluğu $2 \mathrm{~cm}$ artmıştır. (Şekil 3). Olgunun izlem sürecinde kan albümin, üre, ürik asit ve kreatinin değerleri Şekil 4'de verilmiştir.

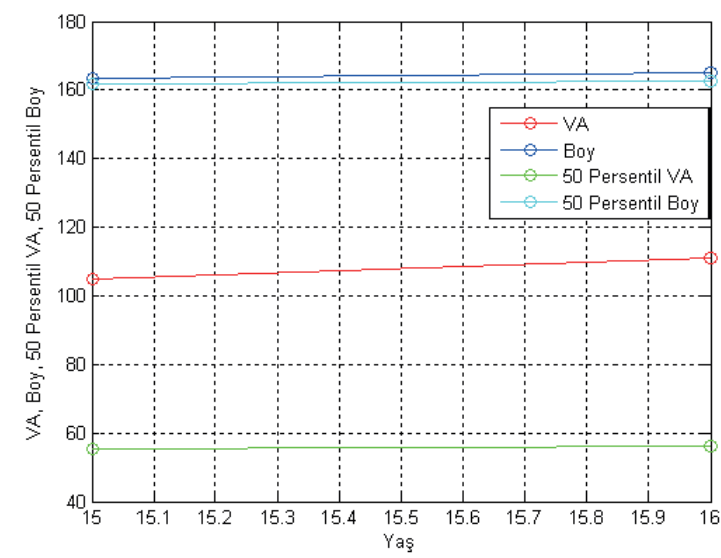

Şekil 3. Olgu 2’nin izlem sürecinde vücut ağırlığı ve boy uzunluğu

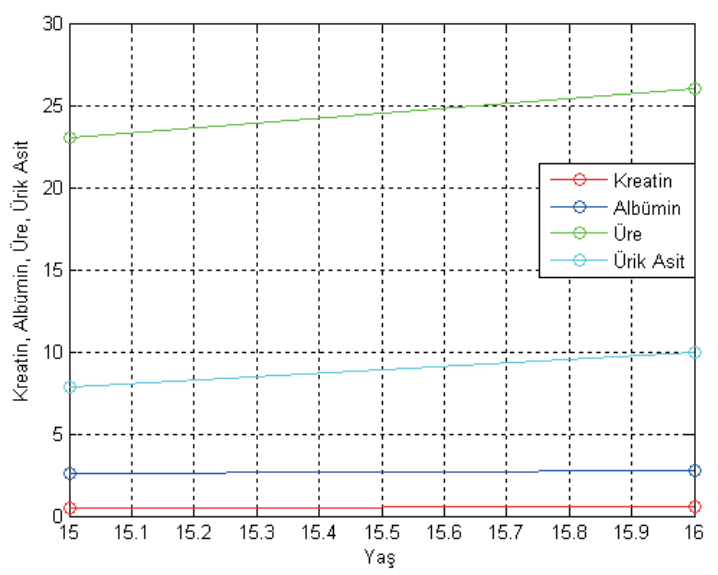

Şekil 4. Olgu 2'nin izlem sürecinde bazı biyokimyasal bulguları

\section{TARTIŞMA}

Dünya genelinde her yaş grubunda yüksek vücut ağırlığı, yüksek BKİ ve morbid obezite dramatik olarak artmaya devam etmektedir (3). Pediatrik Metabolik ve Bariatrik Cerrahi Rehberleri 2018'de adolesanlarda 2012 yılından bu yana yapılan obezite cerrahisi uygulamalarında da önemli bir artış olduğu bildirilmiştir (8). Bu çalışmada ise verilen birinci olgu morbid obez olup, şişmanlığın modern sınıflamasına göre 3. dereceden obezdir (95. persentilin \%140'1, $\mathrm{BKI}=58 \mathrm{~kg} / \mathrm{m}^{2}$ ). İkinci olgu ise obez olup, 2. dereceden obezdir (95. persentilin \%120'si, BKİ= $39.1 \mathrm{~kg} / \mathrm{m}^{2}$ ).

Genel olarak BKI’nin ilerleyici artışı kronik böbrek hastalığı ve son dönem böbrek yetmezliğine geçişi hızlandırmaktadır. Obezitenin sadece primer böbrek hastalıklarını değil aynı zamanda FSGS'yi de ortaya çıkardığı ve erişkinlerde son 20 yılda obezite ile ilişkilendirilen FSGS prevalansının arttığı gözlemlenmiştir $(3,4)$. Bu çalışmada ise ilk olguda morbid obezite ve yoğun adipozite nedeniyle renal biyopsi yapılamamıştır. İkinci olguda ise yapılan renal biyopsi sonrası FSGS tanısı netleştirilmiştir. Ancak elektron mikroskopisi değerlendirmelerinin yetersizliği, obeziteye sekonder FSGS’yi tanımlayacak net kriterlerin olmaması nedeniyle hastaların FSGS'i obeziteyle net olarak ilişkilendirilememiştir.

Obezitenin tedavisinde diyet yönetimi çok önemli bir konu olup, öğün planına hastanın uyumu oldukça zor bir süreçtir. Morbid obez olan ilk olguda 4 ylllık izlem sonucunda vücut ağırlığında bir miktar düşüş olurken son iki yılda tekrar artış sürecine girmiştir. Sedanter yaşayan olgunun hafif derecede mental retardasyonu olması nedeniyle yeme isteği, iştahı hiçbir dönem kontrol altına alınamamıştır. İkinci adolesan kız olgu ise daha aktif olup, elinden gelen gayreti göstermesine rağmen her iki olguda da hedef vücut ağırlığına erişim sağlanamamıştır (Şekil 1-4).

$\mathrm{Bu}$ hastalarda diyet yönetimini zorlaştıran diğer bir önemli nokta ise tedavide kullanılan immün süpresifler ve steroidlerdir. İştahı ve yeme sıklığını arttıran tüm bu etmenler adölesanlarm diyete 
uyumunu zorlaştırmaktadır (4). Ülkemizde morbid obezitenin tedavisinde bariatrik cerrahi uygulamaları yüzyılın en önemli bilimsel ve teknolojik keşfidir. Pediatrik Metabolik ve Bariatrik Cerrahi Rehberleri, morbid obezite sorununun çözümlenmediğinde tüm organlarda ciddi hasarlara yol açtığını bildirmektedir (8). Bu uygulamanin nefrotik sendromlu pediatrik hastalarda kullanımına ilişkin geniş kapsamlı çalışmalara gerek vardır.

Sonuç olarak, immün süpresyonun $\mathrm{mu}$ obeziteye, obezitenin mi FSGS'ye yol açtığı net açıklanamamaktadır. $\mathrm{Bu}$ amaçla yeni tanısal belirteçlerin araştırılması ve bunların ışı̆̆ında tedavi planlarının yapılması gerekmektedir. $\mathrm{Bu}$ konuda yapılacak olan çalışmaların hastaların hayatına çok önemli katkılar sağlayacağı aşikardır. Obezitenin yaşam boyu multidisipliner bir ekip tarafindan izlemi, yaşam tarzı değişiklikleri, diyet yönetimi ve doğru zamanda bariatrik cerrahi uygulamalarına başvurmak, her yaş grubunda birçok hastalığın oluşumunun önüne geçecektir.

Çıkar çatışması - Conflict of interest: Yazarlar çıkar çatışması olmadığını beyan ederler. - The authors declare that they have no conflict of interest.

\section{KAYNAKLAR}

1. Zeybek C, Gök F. Çocuklarda nefrotik sendroma bakış. Türkiye Klinikleri J Nephrol 2015;10:24-42.

2. Düşünsel R, Baştuğ F. Çocuk Nefroloji El Kitabı. Kayseri: Çocuk Nefroloji Derneği Yayını; Kayseri, 2018. Erişim: http://cocuknefroloji.org/wp-content/uploads/2018/01/ cocuk-nefroloji-el-kitabi.pdf3. Amann K, Benz K. Structural renal changes in obesity and diabetes. Semin Nephrol 2013;33:23-33.

3. Praga M, Morales E. The fatty kidney: obesity and renal disease. Nephron 2017;136:273-6.

4. Praga M, Morales E, Herrero JC, Perez Campos A, Dominguez-Gil B, Alegre $\mathrm{R}$, et al. Absense of hypoalbuminemia despite massive proteinuri in focal segmental glomerulosclerosis secondary to hyperfiltration. Am J KidneyDis 1999;33:52-8.

5. Morales E, Valero MA, Leon M, Hernandez E, Praga M. Beneficial effects of weight loss in overweigt patients with chronic proteinuric nephropathies. Am J KidneyDis 2003;41:319-27.

6. Navaneethan SD, Yehnert H, Moustarah F, Schreiber MJ, Schauer PR, Bedhu S. Weight loss interventions in chronic kidney disease: a systematic review and metaanalysis. Clin J Am Soc Nephrol 2009;4:1565-74.

7. Pratte JS, Browne A, Browne NT, Bruzoni M, Cohen M, Desai A, et al. ASMBS pediatric metabolic and bariatric surgery guidelines. Surg Obes Relat Dis 2018;14(7):882901. 